\title{
Biomorfometri Kepiting Bakau di Perairan Bandengan Kendal
}

\author{
Shofi Firda Safitri*, Sunaryo, Ali Djunaedi \\ Departemen IImu Kelautan, Fakultas Perikanan dan IImu Kelautan, Universitas Diponegoro \\ J. Prof.H.Soedarto S.H, Tembalang, Semarang, Jawa Tengah 50275 Indonesia \\ ${ }^{*}$ Corresponding author, e-mail : shofifirda10@gmail.com
}

\begin{abstract}
ABSTRAK: Kepiting Bakau (Scylla sp.) merupakan sumberdaya kelautan penting di Indonesia dan permintaan terhadap komoditi Kepiting Bakau cenderung meningkat, baik di pasar lokal maupun mancanegara. Peningkatan permintaan Kepiting Bakau dapat menyebabkan terganggunya populasi kepiting di alam. Penelitian ini bertujuan untuk mengkaji biomorfometrik Kepiting Bakau (Scylla sp.) yang meliputi ukuran lebar karapas Kepiting Bakau, hubungan lebar karapas dan berat, nisbah kelamin, faktor kondisi dan tingkat kematangan gonad Kepiting Bakau di perairan Bandengan Kendal. Penelitian menggunakan metode deskriptif eksploratif. Hasil penelitian menunjukkan, bahwa jumlah Kepiting Bakau yang diamati sebanyak 1914 ekor, terdiri atas 897 betina dan 1017 jantan, terdapat empat spesies Kepiting Bakau yang tertangkap di perairan Bandengan Kendal, yaitu Scylla serrata, Scylla tranquebarica, Scylla paramamosain dan Scylla olivacea, perbandingan betina dan jantan 1:1,19. Ukuran lebar karapas berkisar antara 43,75$165,5 \mathrm{~mm}$ dengan berat berkisar antara 23-660 g. Hubungan lebar karapas dengan berat bersifat allometrik negatif. Nilai faktor kondisi yang didapatkan berkisar 1,66-1,189. Tingkat kematangan gonad kepiting betina didominasi oleh TKG I dan II, pada bulan November 2018 - Februari 2019 di perairan Bandengan Kendal belum terjadi masa puncak pemijahan.
\end{abstract}

Kata kunci: Scylla sp.; Biomorfometri; Perairan Kendal; Tingkat kematangan gonad

\section{Biomorphometric of Mud Crabs in Bandengan Kendal Waters}

ABSTRACT: Mud crabs (Scylla sp.) are important marine resources in Indonesia and demand for mud crabs tends to increase, both in local and foreign markets. Increased demand for Mangrove Crabs can cause disruption to the population of crabs in nature. This study to examine the morphometrics of Mud Crabs (Scylla sp.) Which include the size of the width of the Mud Crab carapace, the relationship between carapace width and weight, sex ratio, condition factors and the level of maturity of the Mud Crab in Bandengan Kendal waters. The descriptive explorative methods was used in this research. The results showed that the number of mud crabs caught from November 2018 to February 2019 was 1914, consisting of 897 females and 1017 males, there were four species of mud crabs caught in Kendal Bandengan waters, namely Scylla serrata, Scylla tranquebarica, Scylla paramamosain and Scylla olivacea, comparison of females and males 1: 1,19. Carapace widths range from $43.75-165.5 \mathrm{~mm}$ with weights ranging from 23-660 $\mathrm{g}$. The relationship between carapace width and weight are negative allometric. The obtained condition factor values range from 1.66 - 1.189. The maturity level of female crab gonads are dominated by TKG I and II, thus it is suspected that in November 2018 - February 2019 in the waters of Bandengan Kendal, the spawning peak has not yet occurred.

Keywords: Scylla sp.; Biomorphometrics; Kendal Waters; Gonad maturity level

\section{PENDAHULUAN}

Sumber daya ekosistem Bakau yang membentang luas di seluruh kawasan pantai nusantara, menjadikan Indonesia dikenal sebagai pengekspor Kepiting Bakau. Volume ekspor kepiting dan rajungan Indonesia dari Tahun 2015 sampai 2017 mencapai 27,07 ton dengan nilai ekspor mencapai 409,82 Juta USD. Pada bulan Januari-Juni Tahun 2018 peningkatan nilai ekspor kepiting dan rajungan mencapai 14,57 ton dengan nilai ekspor mencapai 241,64 Juta USD (BPS, 
2018). Desa Bandengan di Kabupaten Kendal merupakan salah satu wilayah yang mayoritas masyarakat pesisirnya memanfaatkan Kepiting Bakau, Oleh karena itu tingkat penangkapan fauna ini di Kabupaten Kendal cukup tinggi (Tiurlan et al., 2019).

Masyarakat di daerah Bandengan Kendal umumnya menangkap Kepiting Bakau sebagai bahan pangan disamping untuk memenuhi permintaan pasar lokal dan mancanegara, dibuktikan dari peningkatan nilai ekspor kepiting daerah Jawa Tengah sebesar 45\% pada 2017 atau senilai Rp 273 juta. Sementara itu, untuk kegiatan domestik masuk mengalami peningkatan $115 \%$ pada tahun 2017 atau sekitar Rp 525 juta (BKIPM, 2018). Mencegah terjadinya kepunahan Kepiting Bakau di alam, maka perlu dilakukan upaya pengelolaan penangkapan Kepiting Bakau sesuai dengan Permen KP No. 56/PERMEN-KP/2016, dengan demikian penelitian mengenai studi biomorfometri Kepiting Bakau (Scylla sp.).

Di Indonesia penelitian mengenai aspek biomorfometri Kepiting Bakau telah dilakukan oleh Hardiyanti et al. (2018) di Semarang, Farhaby (2017) di Ulujami Pemalang, Alamsyah (2017) di Kabupaten Sinjai, Herliany dan Zamdial (2015) di Bengkulu, dan Siregar et al. (2017) di Belawan Sicanang. Penelitian biomorfometri Kepiting Bakau di Perairan Bandengan Kendal masih jarang dilakukan. Studi biomorfometri sangat diperlukan sebagai acuan untuk mengetahui kondisi populasi Kepiting Bakau dan dapat digunakan sebagai variabel kunci untuk keberhasilan pengelolaan spesies. Penelitian ini bertujuan untuk mengkaji biomorfometrik Kepiting Bakau (Scylla sp.) yang meliputi ukuran lebar karapas, hubungan lebar karapas dan berat, nisbah kelamin, faktor kondisi dan tingkat kematangan gonad Kepiting Bakau di perairan Bandengan Kendal.

\section{MATERI DAN METODE}

Metode yang digunakan dalam penelitian ini adalah metode deskriptif eksploratif, yaitu metode yang digunakan untuk menganalisis dan menyajikan data secara sistematik, untuk menemukan sesuatu yang baru berupa pengelompokan suatu gejala (Mabrudy, 2013). Sampel Kepiting Bakau (Scylla sp.) yang digunakan dalam penelitian didapatkan dari satu pengepul hasil tangkapan nelayan Kepiting Bakau yang terkumpul di kawasan perairan Bandengan Kendal, Jawa Tengah. Bubu lipat merupakan salah satu alat tangkap yang umum digunakan oleh masyarakat nelayan di Kendal. Sampel Kepiting bakau diambil dari bulan November 2018 - Februari 2019 dengan pengambilan sampel Kepiting Bakau (Scylla sp.) dilakukan sebanyak enam kali di setiap bulan, selama empat bulan penelitian.

Pengukuran lebar karapas Kepiting Bakau mengacu pada Overton et al. (1997). Pengukuran panjang dan lebar karapas digunakan jangka sorong dengan ketelitian 0,01 $\mathrm{mm}$, sedangkan untuk mengukur berat digunakan timbangan digital dengan ketelitian 0,01 g. Kemudian pengamatan jenis kelamin dengan melihat bentuk abdomen kepiting tersebut, dimana jantan memiliki bentuk abdomen yang mengerucut sedangkan pada betina bentuknya yang melebar (KKP, 2016), selanjutnya dilakukan pengamatan terhadap spesies Kepiting Bakau berdasarkan KKP (2016) dan penentuan TKG dilakukan dengan cara mengamati morfologinya yaitu pengamatan gonad kepiting secara visual yang dilakukan di lapangan berdasarkan klasifikasi tingkat kematangan gonad (KKP, 2016). Pengambilan data parameter kualitas air berupa parameter fisika dan parameter kimia meliputi suhu $\left({ }^{\circ} \mathrm{C}\right)$, Salinitas, $\mathrm{pH}$, dan $\mathrm{DO}(\mathrm{mg} / \mathrm{L})$. Pengamatan terhadap parameter kualitas tanah (tekstur tanah) dilakukan secara vertikal.

Analisis data yang digunakan yaitu, (1) Analisis Distribusi Frekuensi Lebar Karapas dan Berat, analisis ini dilakukan terhadap sebaran frekuensi lebar karapas dan berat Kepiting Bakau. Selang kelas, nilai tengah, dan frekuensi diperoleh dengan menggunakan program Microsoft Excel 2013 dalam hal perhitungannya. (2) Analisis Nisbah Kelamin (Sex ratio), Nisbah kelamin atau sex ratio adalah pembagian dari jantan dan betina dalam suatu populasi. Nisbah jantan dan betina ini dapat dihitung menggunakan rumus Effendie (2002). Analisa nisbah kelamin Kepiting Bakau menggunakan uji Chisquare $\left(x^{2}\right)$. (3) Analisis Hubungan Lebar Karapas dan Berat Hubungan Lebar berat digunakan untuk menggambarkan pola pertumbuhan Kepiting Bakau dalam dua bentuk yaitu isometrik dan allometrik dengan menggunakan persamaan Effendie (2002). (4) Analisis Faktor Kondisi, Faktor kondisi menunjukkan keadaan baik buruknya biota dilihat dari segi 
kapasitas fisik. Dilihat dari segi komersil, kondisi ini memiliki arti kualitas dan kuantitas daging yang tersedia. Perhitungan faktor kondisi terlebih dahulu diketahui pola pertumbuhan biota tersebut.

\section{HASIL DAN PEMBAHASAN}

Hasil penelitian menunjukkan bahwa jumlah tangkapan Kepiting Bakau yang ditangkap sebanyak 1.914 ekor, jumlah Kepiting Bakau tertinggi terdapat pada bulan Februari, yaitu 552 ekor dan jumlah kepiting terendah pada bulan Desember, yaitu 403 ekor (Tabel 1). Hasil tangkapan Kepiting Bakau selama penelitian mengalami peningkatan jumlahnya, hal tersebut diduga berkaitan dengan seiring masuknya puncak musim tangkap kepiting yang terjadi pada bulan Januari dan Februari. Sesuai dengan penelitian yang Le Vay (2001) dinyatakan bahwa musim tangkap Kepiting Bakau di perairan pantai Utara Jawa Tengah dimulai bulan September lalu meningkat, mencapai puncaknya pada bulan Januari hingga Februari.

Sedikitnya jumlah Kepiting Bakau pada bulan November dan Desember diduga akibat adanya proses migrasi Kepiting Bakau betina dari perairan mangrove menuju laut, karena menurut Hardiyanti et al. (2018), Kepiting Bakau melakukan proses perkawinan pada musim hujan, yaitu sekitar bulan Oktober - November, sehingga pada saat penelitian di bulan Desember jumlah Kepiting Bakau betina yang ditemukan sedikit karena kepiting betina mulai melakukan migrasi ke laut untuk memijah. Selain itu Tiurlan et al. (2019) menyatakan bahwa pada bulan Oktober Desember terjadi penurunan komposisi kepiting di perairan karena adanya migrasi dari kepiting betina. La Sara et al. (2002), menyatakan bahwa distribusi dan kelimpahan Kepiting Bakau di alam dipengaruhi oleh faktor parameter perairan seperti salinitas dan suhu serta ketersediaan makanan alami. Spesies Kepiting Bakau yang ditemukan pada saat penelitian yaitu Scylla serrata, Scylla paramamosain, Scylla olivacea dan Scylla tranquebarica. Scylla serrata merupakan spesies yang paling banyak tertangkap pada saat penelitian. S. serrata lebih banyak tertangkap diduga berhubungan erat dengan lokasi penangkapan yang sebagian besar berada di kawasan mangrove dan hanya sebagian kecil yang berada di bagian laut. Berdasarkan habitatnya menurut Prasadi et al. (2017) S. serrata lebih banyak hidup di hutan bakau, selain itu S. serrata merupakan spesies Kepiting Bakau yang memiliki toleransi lingkungan yang cukup besar.

Hasil pengukuran lebar karapas maupun berat Kepiting Bakau diperoleh 11 kelas ukuran pada spesies Scylla serrata (Gambar 1). Spesies Scylla paramamosain dan Scylla olivacea diperoleh 7 kelas ukuran lebar dan berat, sedangkan pada spesies Scylla tranquebarica diperoleh 6 kelas ukuran lebar dan berat, seperti yang terlihat pada Gambar 1 dan 2. Berdasarkan kisaran ukuran lebar karapas Kepiting Bakau betina dan jantan hasil tangkapan di perairan Bandengan untuk spesies Scylla serrata memiliki kisaran ukuran lebar karapas antara 43,75 - 165,62 mm dengan kisaran ukuran berat, yaitu 23 - $671 \mathrm{~g}$; Spesies Scylla paramamosain memiliki kisaran lebar 62,25 - 120,62 mm dengan kisaran berat 43 - $392 \mathrm{~g}$; Scylla olivacea memiliki kisaran lebar 61,75 - 126,56 mm dengan kisaran berat 45 - $303 \mathrm{~g}$ dan Scylla tranquebarica memiliki kisaran lebar 61,75 - 126,78 $\mathrm{mm}$ dengan kisaran berat $46-291 \mathrm{~g}$.

Ukuran lebar karapas Kepiting Bakau yang tertangkap pada semua spesies sebagian besar berukuran kecil, hal tersebut diduga terjadi karena adanya rekrutmen yaitu mulai masuknya kepiting hasil pemijahan bulan sebelumnya ke area mangrove, dikarenakan adanya ekosistem

Tabel 1. Jumlah Kepiting Bakau (ekor) Jantan dan Betina Hasil Tangkapan di Perairan Bandengan Kendal Bulan November 2018 sampai Februari 2019

\begin{tabular}{cccc}
\hline Bulan & Betina & Jantan & Jumlah \\
\hline November & 212 & 222 & 434 \\
Desember & 148 & 255 & 403 \\
Januari & 265 & 260 & 525 \\
Februari & 272 & 280 & 552 \\
\hline Jumlah & 897 & 1017 & 1914 \\
\hline
\end{tabular}




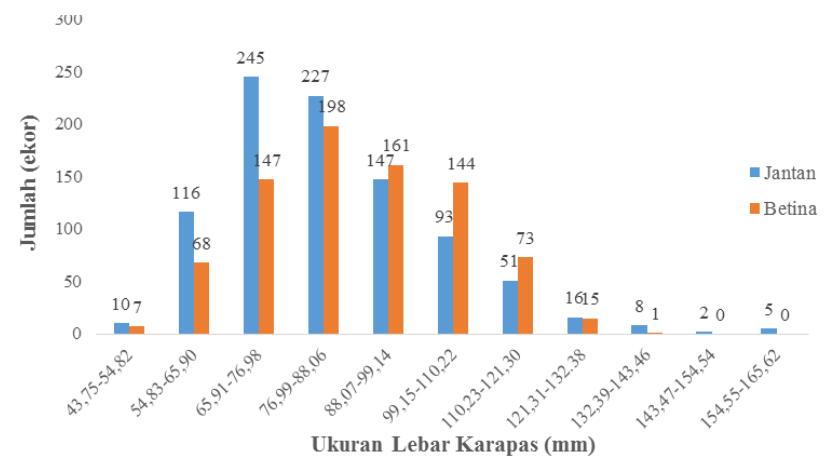

Scylla serrata

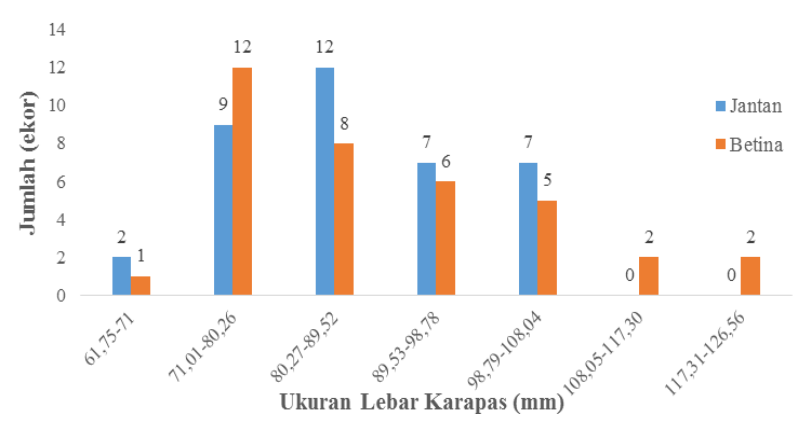

Scylla olivacea

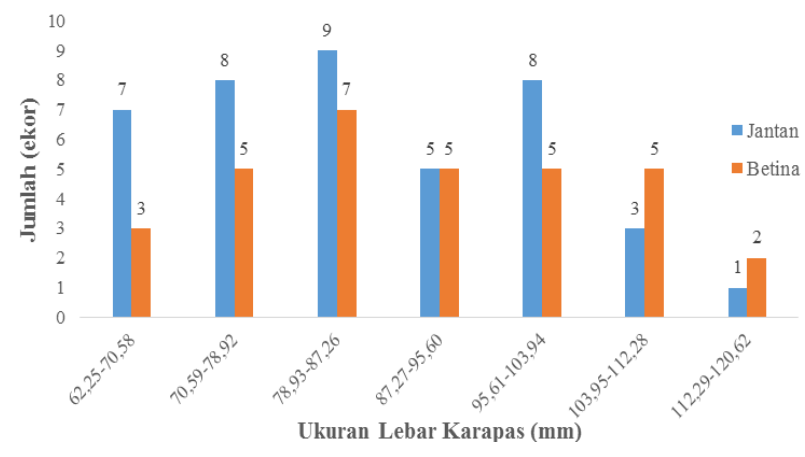

Scylla paramamosain

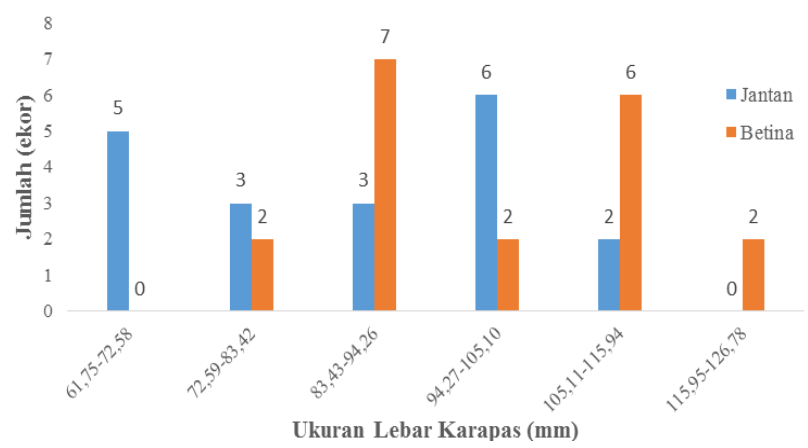

Scylla tranquebarica

Gambar 1. Distribusi Ukuran Kelas Lebar Karapas Kepiting Bakau (Scylla sp.) Jantan dan Betina Hasil Tangkapan di Perairan Bandengan Kendal

mangrove berupa Rhizopohora sp. dan Avicennia sp. di daerah penelitian, dimana menurut Pratiwi (2011) menyatakan bahwa Kepiting Bakau muda (stadia juvenil) akan bermigrasi kembali ke hulu estuari, kemudian berangsur - angsur memasuki kawasan hutan mangrove hingga berkembang menjadi Kepiting Bakau dewasa. Sedangkan Kepiting Bakau dewasa sedikit ditemukan karena aktivitas penangkapan dan adanya migrasi Kepiting Bakau betina ke tengah laut untuk memijah.

Menurut Siregar et al. (2017) Penangkapan yang dilakukan secara terus menerus mengakibatkan Kepiting Bakau yang berukuran besar cenderung menurun, sehingga struktur populasi Kepiting Bakau mengalami degradasi. Ukuran lebar karapas Kepiting Bakau yang didapat sebagian besar lebih kecil dibandingkan dengan ukuran yang ditetapkan oleh pemerintah dalam Permen - KP No. 56/PERMEN-KP/2016 yang menyatakan bahwa ukuran lebar karapas Kepiting Bakau yang boleh ditangkap adalah sebesar $150 \mathrm{~mm}$. Sedangkan ukuran berat Kepiting Bakau jantan dan betina di Perairan Bandengan Kendal yang tertangkap < $200 \mathrm{~g}$ sebesar 97,86\% merupakan Kepiting Bakau tidak layak tangkap dan >200 g sebesar 2,14\% merupakan Kepiting Bakau yang layak tangkap. Kepiting Bakau yang tertangkap selama penelitian belum sesuai dengan Permen KP No. 56/PERMEN-KP/2016 karena sebagian besar merupakan Kepiting Bakau yang memiliki berat < $200 \mathrm{~g}$. Dapat disimpulkan bahwa Kepiting Bakau yang tertangkap selama penelitian merupakan kepiting muda dan dikhawatirkan belum memasuki musim pemijahan.

Nisbah kelamin merupakan perbandingan antara jumlah kepiting bakau betina dengan jantan dalam suatu populasi dan penting diketahui karena berpengaruh terhadap kestabilan populasi. Hasil penelitian menunjukkan bahwa pada bulan November diperoleh Kepiting Bakau sebanyak 212 ekor Kepiting Bakau betina dan 222 ekor Kepiting Bakau jantan dengan nisbah kelamin 1 : 1,05. Sedangkan bulan Desember didapat 148 ekor Kepiting Bakau betina dan 255 ekor Kepiting Bakau jantan dengan nisbah kelamin $1: 1,72$. Selanjutnya pada bulan Januari didapat 265 ekor Kepiting Bakau betina dan 260 ekor Kepiting Bakau jantan dengan nisbah kelamin 1,02 : 1. Bulan 
Februari didapat 272 ekor Kepiting Bakau betina dan 280 ekor Kepiting Bakau jantan dengan nisbah kelamin $1: 1,03$ (Tabel 2).

Berdasarkan hasil penelitian diperoleh perbedaan perbandingan rasio, pada bulan November, Desember dan Februari lebih banyak tangkapan Kepiting Bakau Jantan sedangkan pada bulan Januari lebih banyak Kepiting Bakau betina tetapi masih dalam kategori seimbang. Berdasarkan uji chi-square pada bulan Desember didapatkan ketidakseimbangan antara kepiting jantan dan betina dengan rasio 1,72:1. Ketidakseimbangan antara jantan dan betina pada bulan Desember diduga karena bulan ini merupakan musim pemijahan kepiting sehingga sebagian besar kepiting betina sudah berada di laut untuk melakukan pemijahan. Hal ini sesuai dengan pernyataan Romimohtarto dan Juwana (2005) bahwa Kepiting Bakau memijah sepanjang tahun dengan memiliki 4 musim puncak pemijahan yaitu, musim barat terjadi di bulan Desember, musim peralihan I di bulan Maret, musim Timur di bulan Juli dan peralihan II di bulan September. Selain itu menurut Pratiwi (2011), Kepiting Bakau betina akan bermigrasi ke perairan laut atau menjauhi pantai untuk mencari perairan yang parameter lingkungannya (terutama suhu dan salinitas) cocok sebagai tempat memijah.

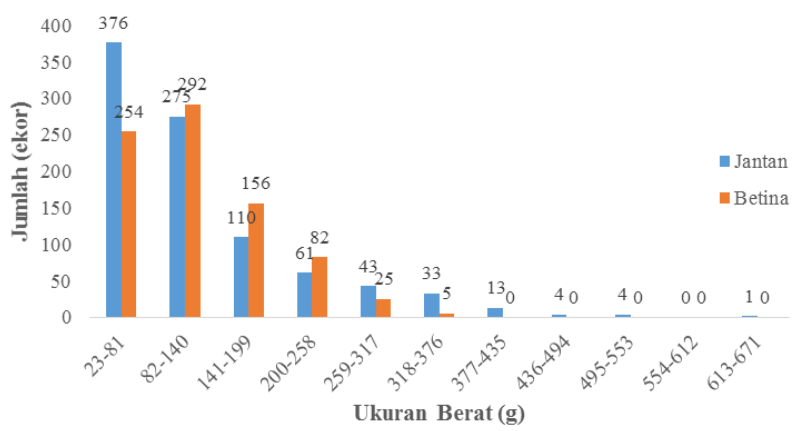

Scylla serrata

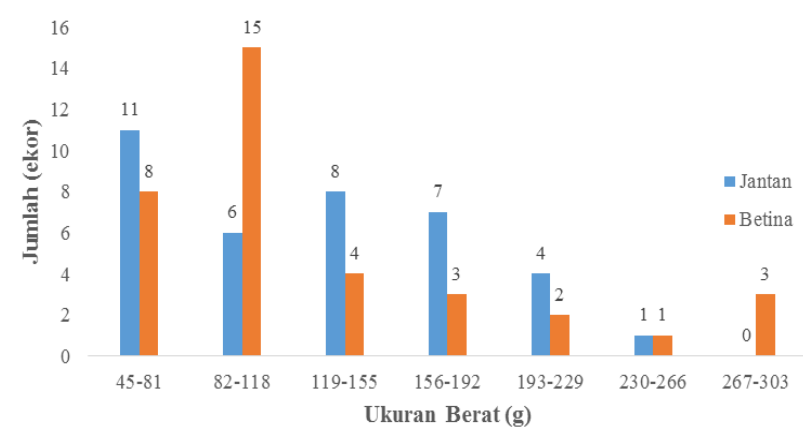

Scylla olivacea

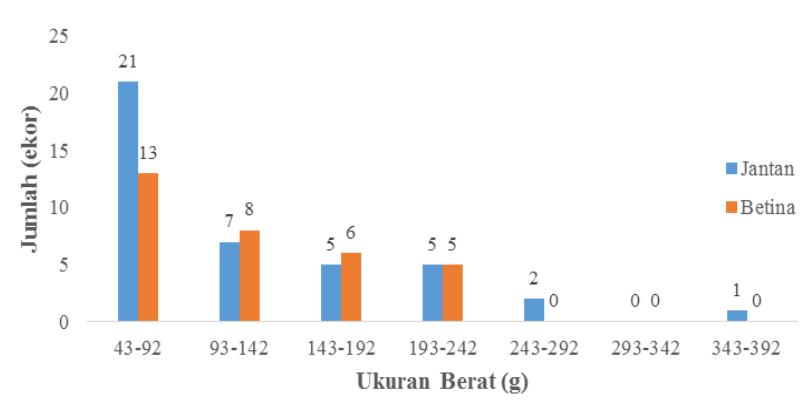

Scylla paramamosain

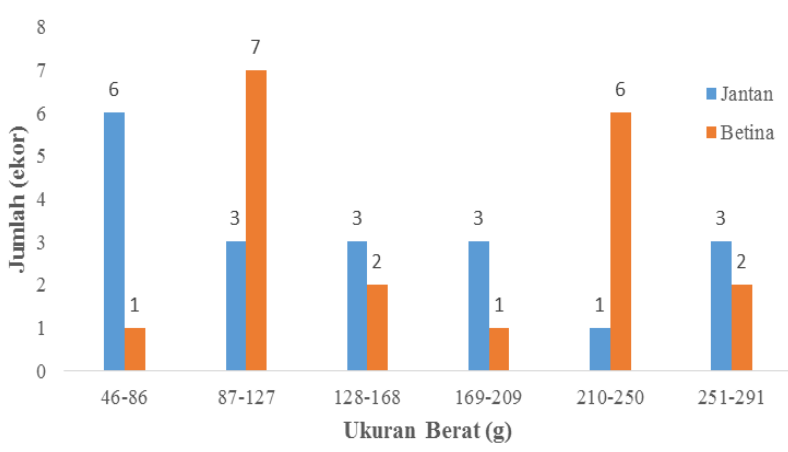

Scylla tranquebarica

Gambar 2. Distribusi Frekuensi Ukuran Berat Scylla sp. Jantan dan Betina Hasil Tangkapan di Perairan Bandengan Kendal

Tabel 2. Nisbah Kelamin Kepiting Bakau Scylla sp. Betina dan Jantan

\begin{tabular}{cccccccc}
\hline \multirow{2}{*}{ Waktu Sampling } & \multicolumn{2}{c}{ Jumlah (ekor) } & \multicolumn{6}{c}{ Nisbah Kelamin (Rasio) } & \multirow{2}{*}{$x^{2}$ hitung } & \multirow{2}{*}{ X tabel } & \multirow{2}{*}{ Keputusan } \\
\cline { 2 - 6 } & $\mathrm{B}$ & $\mathrm{J}$ & $\mathrm{B}$ & $\mathrm{J}$ & & & \\
\hline November & 212 & 222 & 1 & 1,05 & 0,23 & 10,825 & Seimbang \\
Desember & 148 & 255 & 1 & 1,72 & 28,409 & 10,05 & Tidak Seimbang \\
Januari & 265 & 260 & 1,02 & 1 & 6,25 & 13,5 & Seimbang \\
Februari & 272 & 280 & 1 & 1,03 & 0,116 & 13,775 & Seimbang \\
Jumlah & 897 & 1017 & 1 & 1,19 & 35,005 & 48,15 & \\
\hline
\end{tabular}




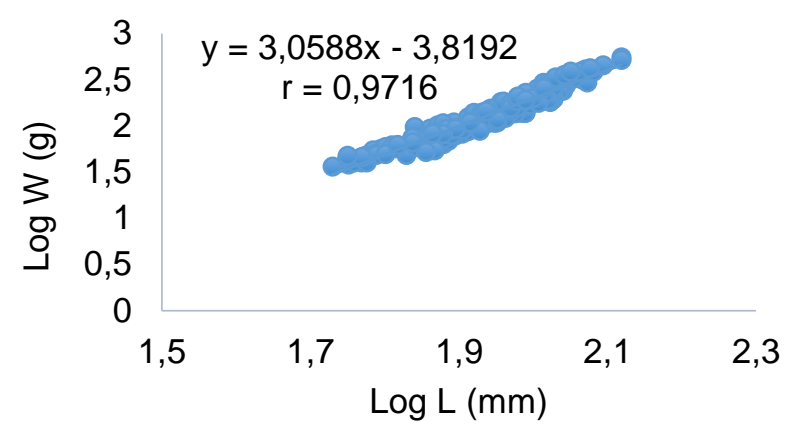

November 2018 (jantan)

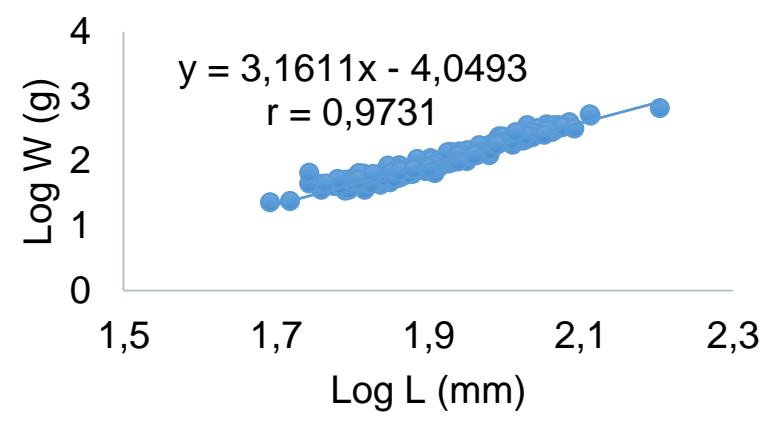

Desember 2018 (jantan)

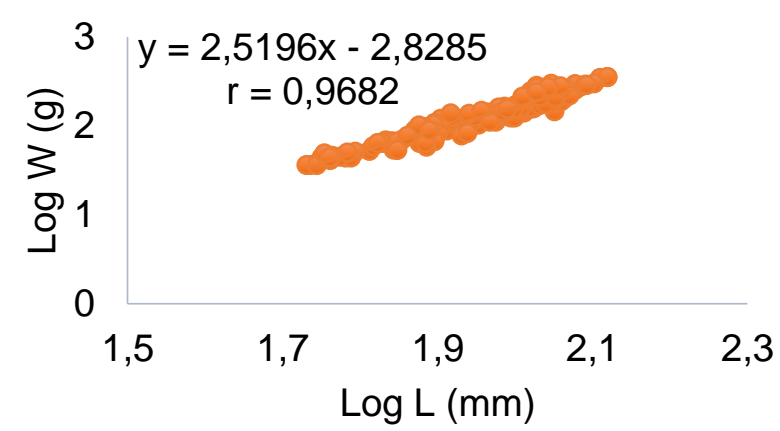

November 2018 (betina)

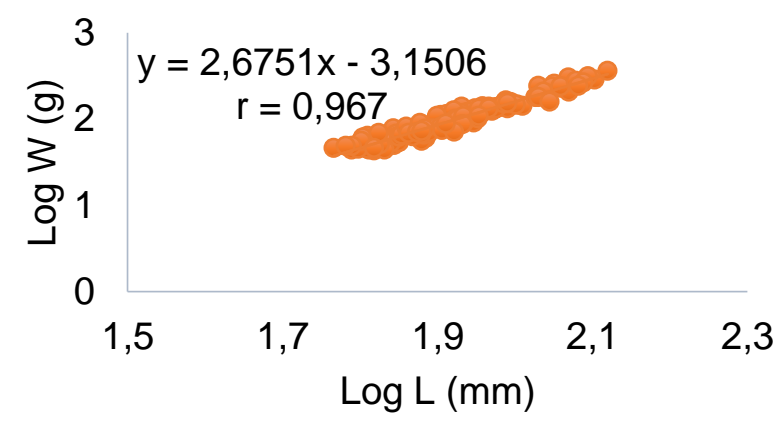

Desember 2018 (betina)

Gambar 3. Grafik Hubungan Lebar Karapas dan Berat Kepiting Bakau di Perairan Bandengan Kendal.

Analisis hubungan lebar karapas dan berat digunakan untuk mengetahui pola pertumbuhan Kepiting Bakau. Pola pertumbuhan (b) Kepiting Bakau dianalisis menggunakan regresi dengan melihat hubungan antara lebar karapas dengan berat Kepiting Bakau. Dapat dilihat pada Gambar 3 dan 4, nilai slope (b) yang didapatkan di perairan Bandengan Kendal (November, Desember, Januari dan Februari) untuk Kepiting Bakau betina berkisar 2,3355-2,6751 dan Kepiting Bakau jantan 2,4222-3,1611. Secara keseluruhan Kepiting Bakau betina dan jantan memiliki nilai $b \neq 3$ yang menunjukkan bahwa pertumbuhan Kepiting Bakau bersifat allometrik, yaitu pertumbuhan lebar lebih lambat atau lebih cepat dari pertumbuhan berat.

Nilai b pada kepiting betina pada keempat bulan didominasi pola pertumbuhan allometrik negatif $(b<3)$, yaitu pertambahan lebar karapas lebih cepat dibandingkan pertambahan bobot tubuh. Yunus et al. (2018), bahwa Kepiting Bakau betina yang memiliki pola pertumbuhan allometrik negatif disebabkan karena Kepiting Bakau betina menggunakan asupan makanan lebih banyak untuk moulting dan proses kematangan gonad, sehingga pertumbuhan Kepiting Bakau betina cenderung lebih ke arah lebar karapas karena kepiting betina akan moulting setiap akan melakukan proses kopulasi. Menurut Herliany dan Zamdial (2015), setiap terjadi pelepasan cangkang (moulting) tubuh kepiting akan bertambah berat sekitar 1/3 kali dari sebelumnya dan lebar karapas akan meningkat 5-10 mm (sekitar 2 kali dari ukuran semula) pada kepiting dewasa. Sedangkan Perbedaan antara allometrik positif dan negatif pada Kepiting Bakau jantan, menurut Yunus et al. (2018) diduga terjadi karena faktor-faktor yang mempengaruhi pertumbuhan crustacea meliputi dua faktor, yaitu faktor internal dan eksternal. Faktor internal meliputi ukuran, jenis kelamin, tingkat kedewasaan, dan cacat tubuh. Sedangkan yang termasuk dalam faktor eksternal, yaitu ketersediaan makanan, suhu, dan salinitas. Pada saat Kepiting Bakau betina beruaya ke laut untuk memijah, Kepiting Bakau jantan tetap berada di perairan hutan mangrove untuk mencari makan, yang kemudian akan mengalokasikan stok nutrisi dan energi yang diperoleh dari makanannya untuk pertumbuhan. Nilai koefisien korelasi $(r)$ untuk persamaan Kepiting Bakau 
jantan dan betina di Perairan Bandengan Kendal adalah berkisar antara 0,9221 - 0,9731; nilai tersebut menunjukkan korelasi yang kuat antara lebar karapas dengan berat Kepiting Bakau dimana setiap Kepiting Bakau mengalami penambahan lebar karapas maka berat tubuh juga akan bertambah. Hal ini sesuai dengan pendapat Yunus et al. (2018) bahwa, apabila nilai koefisien korelasi 0,40 - 0,69, maka menunjukkan korelasi sedang, sedangkan apabila nilai koefisien korelasi 0,70 - 0,89 menunjukkan korelasi kuat.

Faktor kondisi yaitu suatu keadaan yang menggambarkan kegemukan dari Kepiting Bakau. Berdasarkan hasil penelitian menunjukkan nilai faktor kondisi $(\mathrm{Kn})$ Kepiting Bakau jantan berkisar antara 1,120-1,189 sedangkan kepiting betina berkisar 1,066-1,092 (Tabel 4). Nilai yang didapatkan pada setiap bulannya tidak berbeda jauh. Hal tersebut menunjukkan bahwa Kepiting Bakau pada semua bulan tergolong pipih atau tidak gemuk sesuai dengan Effendie (2002) yang menyatakan bahwa nilai faktor kondisi $0-1$, maka ikan tersebut tergolong pipih atau tidak gemuk. Faktor yang menyebabkan faktor kondisi yang rendah (tergolong pipih), salah satunya faktor lingkungan yaitu kurangnya ketersediaan makanan dilokasi penelitian. Lokasi penangkapan Kepiting Bakau mayoritas di wilayah pertambakan, mangrove tumbuh di sekeliling petakan tambak dan mempunyai tegakan mangrove yang tidak terlalu rapat, sehingga serasah yang dihasilkan tidak terlalu banyak, hal tersebut menyebabkan kurangnya ketersediaan makanan untuk Kepiting Bakau. Faktor kondisi yang tinggi menunjukkan kepiting dalam perkembangan gonad, sedangkan faktor kondisi yang rendah menunjukkan kepiting kurang mendapat asupan makanan.

Pengamatan terhadap kematangan gonad Kepiting Bakau dilakukan secara morfologi pada semua sampel. Selama penelitian didapatkan Kepiting Bakau betina berjumlah 897 ekor, 547 ekor belum memasuki masa matang gonad, dan 350 ekor sudah memasuki matang gonad, kepiting yang belum matang gonad sepenuhnya berjumlah 279 ekor dan 268 ekor sudah matang gonad sepenuhnya (Tabel 5). Kepiting betina yang mulai memasuki matang gonad didapatkan pada bulan November yaitu 141 ekor Kepiting Bakau betina, dalam kondisi belum matang penuh yaitu $69,5 \%$ dan 30,5\% sudah matang penuh. Selanjutnya di bulan Desember didapatkan 42 ekor

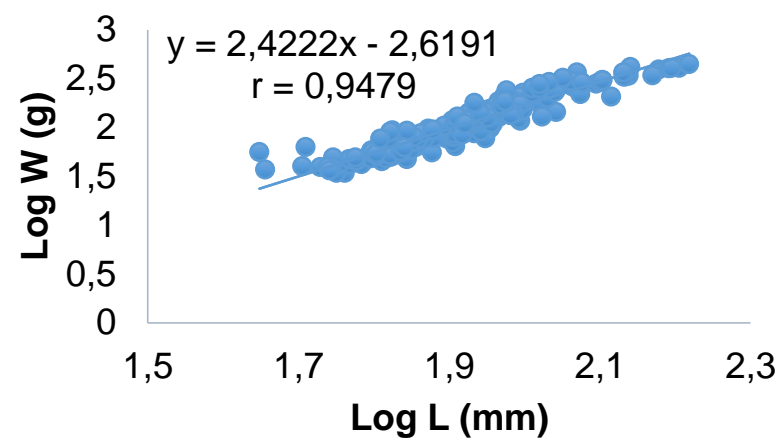

Januari 2019 (jantan)

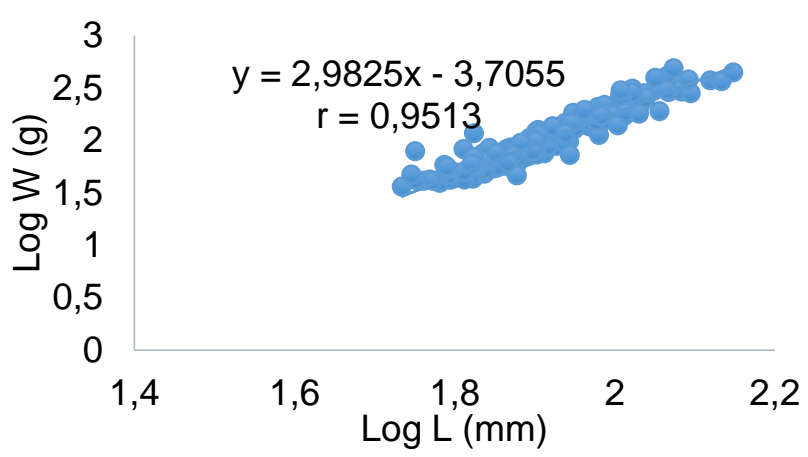

Februari 2019 (jantan)

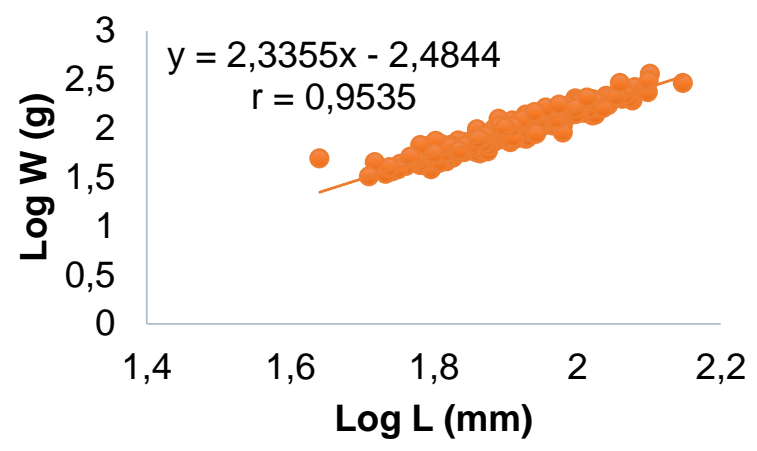

Januari 2019 (betina)

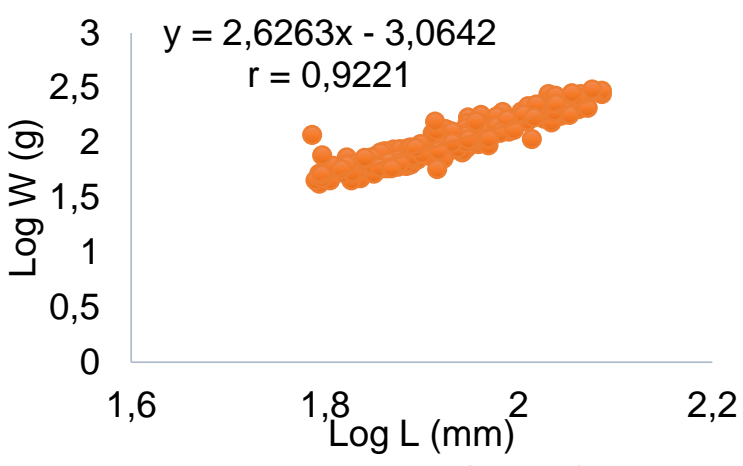

Februari 2019 (betina)

Gambar 4. Grafik Hubungan Lebar Karapas dan Berat Kepiting Bakau di Perairan Bandengan Kendal 
Tabel 4. Hasil Penghitungan Faktor Kondisi Kepiting Bakau di Perairan Bandengan Kendal

\begin{tabular}{ccccccc}
\hline $\begin{array}{c}\text { Waktu } \\
\text { Sampling }\end{array}$ & JK & $\begin{array}{c}\text { Kisaran Lebar Karapas } \\
(\mathrm{mm})\end{array}$ & $\begin{array}{c}\text { Kisaran Berat } \\
(\mathrm{gram})\end{array}$ & $\begin{array}{c}\text { Rata-rata Lebar karapas } \\
(\mathrm{mm})\end{array}$ & $\begin{array}{c}\text { Rata-rata berat } \\
(\mathrm{gram})\end{array}$ & $\mathrm{Kn}$ \\
\hline \multirow{2}{*}{ November } & $\mathrm{J}$ & $53,7-131,5$ & $36-548$ & 88,59 & 154,94 & 1,126 \\
& $\mathrm{~B}$ & $53,8-131,75$ & $36-353$ & 96,82 & 160,37 & 1,071 \\
\multirow{2}{*}{ Desember } & $\mathrm{J}$ & $49,25-160$ & $23-660$ & 82,05 & 119,27 & 1,189 \\
& $\mathrm{~B}$ & $58,35-131,75$ & $43-362$ & 85,22 & 112,76 & 1,092 \\
\multirow{3}{*}{ Januari } & $\mathrm{J}$ & $44,5-165,5$ & $34-442$ & 85,94 & 130,41 & 1,120 \\
& $\mathrm{~B}$ & $43,75-140,5$ & $32-359$ & 87,36 & 120,34 & 1,073 \\
\multirow{2}{*}{ Februari } & $\mathrm{J}$ & $54,25-140,75$ & $36-482$ & 81,88 & 114,58 & 1,144 \\
& $\mathrm{~B}$ & $61,25-121,95$ & $42-304$ & 85,70 & 109,73 & 1,066 \\
\hline
\end{tabular}

Keterangan : JK = Jenis kelamin, $\mathrm{J}=$ Jantan, $\mathrm{B}=$ Betina dan $\mathrm{Kn}=$ Faktor kondisi

Tabel 5. Tingkat Kematangan Gonad Kepiting Bakau (Scylla sp.) Betina di Perairan Bandengan Kendal

\begin{tabular}{|c|c|c|c|c|c|}
\hline Waktu Sampling & $\overline{T K G}$ & Betina (ekor) & Presentase (\%) & Jumlah Presentase TKG & Keterangan \\
\hline \multirow[t]{4}{*}{ November } & I & 28 & 20 & \multirow{2}{*}{69,5} & \multirow{2}{*}{ Belum matang } \\
\hline & II & 70 & 50 & & \\
\hline & III & 38 & 27 & \multirow{2}{*}{30,5} & \multirow{2}{*}{ Matang } \\
\hline & IV & 5 & 3,5 & & \\
\hline \multirow[t]{4}{*}{ Desember } & I & 18 & 43 & \multirow{2}{*}{71,4} & \multirow{2}{*}{ Belum matang } \\
\hline & ॥ & 12 & 29 & & \\
\hline & III & 12 & 29 & \multirow{2}{*}{28,6} & \multirow{2}{*}{ Matang } \\
\hline & IV & 0 & 0 & & \\
\hline \multirow[t]{4}{*}{ Januari } & I & 48 & 64 & \multirow{2}{*}{96} & \multirow{2}{*}{ Belum matang } \\
\hline & II & 24 & 32 & & \\
\hline & III & 3 & 4 & \multirow{2}{*}{4} & \multirow{2}{*}{ Matang } \\
\hline & IV & 0 & 0 & & \\
\hline \multirow[t]{4}{*}{ Februari } & I & 53 & 58 & \multirow{2}{*}{85,9} & \multirow{2}{*}{ Belum matang } \\
\hline & II & 26 & 28 & & \\
\hline & III & 10 & 11 & \multirow{2}{*}{14,1} & \multirow{2}{*}{ Matang } \\
\hline & IV & 3 & 3,3 & & \\
\hline
\end{tabular}

kepiting betina mulai memasuki matang gonad, dalam kondisi belum matang penuh $71,4 \%$ dan $28,6 \%$ sudah matang. Sedangkan di bulan Januari didapatkan 75 ekor kepiting betina yang mulai matang gonad, dalam kondisi belum matang penuh $96 \%$ dan $4 \%$ sudah matang. Bulan Februari didapatkan 92 ekor Kepiting Bakau betina mulai memasuki matang gonad, dalam kondisi belum matang penuh 85,9\% dan sudah matang sebesar 14,1\% (Tabel 5). Gonad Kepiting Bakau betina dikatakan matang apabila sudah mencapai TKG III dan TKG IV.

Berdasarkan hasil penelitian yang dilakukan, jumlah Kepiting Bakau TKG I dan TKG II paling banyak ditemukan. Hasil yang didapat pada penelitian ini serupa dengan hasil penelitian Sianturi et al. (2016) di kawasan hutan mangrove Sicanang, Medan Belawang Sumatera Utara, jumlah Kepiting Bakau TKG I dan TKG II paling banyak dikarenakan sumber makanan yang minim dan kondisi lingkungan yang kurang sesuai. Menurut Kasri (1991) diacu dalam Endrawati et al. (2004) bahwa pada saat kepiting dalam fase reproduksi akan membutuhkan kuantitas pakan serta kualitas nutrisi yang mencukupi untuk menunjang proses-proses reproduksi dan kematangan gonad. Faktor lain yang mempengaruhi adalah adanya migrasi pada Kepiting Bakau betina pada 
TKG III dan TKG IV menuju ke tengah laut, hal ini sesuai dengan Kumalah et al. (2017) Kepiting Bakau melangsungkan perkawinan di perairan mangrove dan secara berangsur-angsur sesuai dengan perkembangan telurnya, Kepiting Bakau betina akan bermigrasi ke perairan laut untuk memijah. Migrasi Kepiting Bakau betina matang gonad ke perairan laut, merupakan upaya mencari perairan yang kondisinya cocok sebagai tempat memijah, inkubasi, dan menetaskan telur (Kumalah et al., 2017).

Parameter kondisi lingkungan memiliki peran penting pada siklus kehidupan setiap makhluk hidup dan berbagai jenis biota yang ada di berbagai ekosistem, hal tersebut juga berlaku pada Kepiting Bakau (Scylla sp.). Suhu merupakan salah satu faktor lingkungan yang mempengaruhi kehidupan Kepiting Bakau. Berdasarkan penelitian yang dilakukan, kisaran suhu yang didapat yaitu $25-30,1^{\circ} \mathrm{C}$, Suhu air yang didapat selama penelitian stabil yaitu tidak ada perubahan yang drastis. Fluktuasi suhu pada penelitian ini sudah cukup optimal untuk menunjang siklus hidup dan pertumbuhan Kepiting Bakau Scylla sp. sesuai dengan hasil penelitian Adha (2018), di kawasan mangrove desa Bedono Demak yaitu Kepiting Bakau mampu bertahan hidup pada suhu $12-35^{\circ} \mathrm{C}$, dan dapat tumbuh optimal pada suhu $23-32^{\circ} \mathrm{C}$.

Nilai salinitas selama penelitian berkisar antara 15-30 ppt. Kisaran salinitas 15-30 ppt pada saat penelitian sudah sesuai dengan baku mutu air laut bagi biota menurut Keputusan Menteri Lingkungan Hidup Nomor 51 Tahun 2004 dalam penelitian berjudul Jenis Kepiting Bakau (Scylla sp.) yang Tertangkap di Perairan Labuhan Bahari Belawan Medan oleh Haeruddin et al. (2013). yaitu 10 - 30 ppt, artinya kisaran salinitas tersebut dapat ditoleransi oleh Kepiting Bakau untuk mendukung tumbuh dan berkembangnya kepiting. Kisaran oksigen terlarut perairan yang didapatkan dari hasil penelitian adalah berkisar antara 4,6-8,7. Kandungan oksigen terlarut di lokasi penelitian ini masih memenuhi kriteria untuk kehidupan Kepiting Bakau, sesuai dengan pernyataan Susanto dan Muwarni (2006) yang menyatakan bahwa kebutuhan oksigen untuk kehidupan Kepiting Bakau adalah $>4 \mathrm{mg} / \mathrm{L}$, sedangkan kebutuhan oksigen untuk pertumbuhan maksimal Kepiting Bakau adalah $>5 \mathrm{mg} / \mathrm{L}$.

Nilai $\mathrm{pH}$ yang didapatkan dari hasil penelitian adalah berkisar antara 6,25-8,1. Pada penelitian yang dilakukan oleh Pertiwi pada tahun 2005, nilai $\mathrm{pH}$ perairan di lokasi penelitian (Kalimantan Timur) berkisar antara 6,2-7,5 dan nilai ini normal bagi Kepiting Bakau. Menurut Sari (2004) pada penelitiannya di habitat mangrove Ulee Lheue (Banda Aceh) dalam Haeruddin et al. (2013) mendapatkan nilai $\mathrm{pH}$ perairan pada kisaran 6,09-7,83 yang juga tergolong dalam keadaan normal dan baik untuk kehidupan kepiting. Jadi nilai pH kisaran 6,25-8,1 pada lokasi penelitian dapat ditoleransi oleh Kepiting Bakau dan tergolong dalam keadaan normal untuk kehidupan Kepiting Bakau. Berdasarkan analisis substrat lokasi penelitian di titik I yaitu silt loam (lempung berdebu) sedangkan pada titik II dan III yaitu silty clay loam (lempung liat berdebu). Substrat tersebut baik bagi kehidupan Kepiting Bakau, sesuai dengan Setiawan dan Triyanto (2012) tekstur substrat dasar yang baik bagi kehidupan Kepiting Bakau terdiri dari lempung berpasir (Sandy loam) atau tanah lempung berdebu (silty loam) dan tidak bocor (porous) yang berfungsi untuk menahan air.

\section{KESIMPULAN}

Ukuran lebar karapas dan berat tubuh Kepiting Bakau lebih banyak tergolong Kepiting Bakau remaja (subadult) dan Kepiting Bakau muda (juvenile). Rasio (jantan : betina) tangkapan Kepiting Bakau pada bulan November 2018 sampai Februari 2019 masih dalam kategori seimbang, yaitu 1,19:1. Kepiting Bakau jantan selama penelitian memiliki pola pertumbuhan allometrik positif. Kepiting Bakau betina memiliki pola pertumbuhan allometrik negative.

\section{DAFTAR PUSTAKA}

Effendie, M. I., 2002. Biologi Perikanan. Yayasan Pustaka Nusatama Yogyakarta.

Endrawati, H., M. Zainuri, C.A. Suryono, \& Suryono. 2004. Pengaruh Kepadatan Terhadap Tingkat Kematangan Gonad dan Fekunditas Kepiting Bakau (Scylla serrata) Pada Kultivasi di Tambak Garam. Jurnal IImu Kelautan, 9(4):196-201. 
Haeruddin, Hia, P.M.F. \& Hendrarto, B. 2013. Jenis Kepiting Bakau (Scylla sp.) yang Tertangkap di Perairan Labuhan Bahari Belawan Medan. Journal of Management of Aquatic Resources, 2(3):170-179.

Hardiyanti, A.S., Sunaryo, Ritniasih I. \& Santoso, A. 2018. Biomorfometrik Kepiting Bakau (Scylla sp.) Hasil Tangkapan di Perairan Semarang. Buletin Oseanografi Marina, 7(2): 81 - 90.

Herliany, N.E. \& Zamdial, Z., 2015. Hubungan Lebar Karapas Dan Berat Kepiting Bakau (Scylla spp.) Hasil Tangkapan Di Desa Kahyapu Pulau Enggano Provinsi Bengkulu. Jurnal Kelautan: Indonesian Journal of Marine Science and Technology, 8(2):89-94.

Kumalah, A., Wardiatno, Y., Setyobudiandi, I. \& Fahrudin, A. 2017. Biologi Populasi Kepiting Bakau Scylla serrata - Forsskal, 1775 Di Ekosistem Mangrove Kabupaten Subang, Jawa Barat. Jurnal Ilmu dan Teknologi Kelautan Tropis, 9(1):173-184.

Levay, L. 2001. Ecology and Management of The Mud Crab, Scylla spp. Asian Fisheries Science, 14:101-111.

Prasadi, O., Sulistyo, I., Winanto, T. \& Dewi, N.N., 2017. Bioekologi Kepiting Bakau (Scylla serrata dan Scylla oceanica) Di Kawasan Desa Ambulu, Kecamatan Losari, Kabupaten Cirebon. Journal of Marine and Coastal Science, 6(2), pp.56-68. Pratiwi, R. 2011. Biologi Kepiting Bakau (Scylla spp.) di Perairan Indonesia. Oseana, 36(1):1-11.

Setiawan, F. \& Triyanto. 2012. Studi Kesesuaian Lahan untuk Pengembangan Silvofishery Kepiting Bakau di Kabupaten Berau, Kalimantan Timur. Limnotek, 19(2):158-165.

Sianturi, A., Basyuni, M. \& Apandy, Z., 2016. Tingkat Kematangan Gonad Kepiting Bakau (scylla serrata) di Kawasan Hutan Mangrove Sicanang Kecamatan Medan Belawan Sumatera Utara Aquacoastmarine, 12(2):38-47.

Siregar, D.S., Sitorus, H. \& Suryanti, A., Karakter Morfometrik dan Meristik Kepiting Bakau (Scylla serrata) di Perairan Mangrove Kampung Sentosa Barat Kelurahan Belawan Sicanang Kecamatan Medan Belawan. Aquacoastmarine, 5(4):128-137.

Kementerian Kelautan dan Perikanan [KKP], 2016. Pedoman Pemeriksaan/Identifikasi Jenis Ikan Dilarang Terbatas (Kepiting Bakau/Scylla spp.). diterbitkan oleh Pusat Karantina dan Keamanan Hayati Ikan Badan Karantina Ikan, Pengendalian Mutu dan Keamanan Hasil Perikanan Kementerian Kelautan dan Perikanan. ISBN 978602-97141-1-1.

Susanto, G.N. \& Murwani. 2006. Analisis secara Ekologis Tambak Alih Lahan pada Kawasan Potensial untuk Habitat Kepiting Bakau (Syclla spp.) Prosiding Seminar Nasional Limnologi 2006 Puslit Limnologi-LIPI, 284-292.

Tiurlan, E., Djunaedi, A. and Supriyantini, E., 2019. Analisis Aspek Reproduksi Kepiting Bakau (Scylla sp.) di Perairan Kendal, Jawa Tengah. Journal of Tropical Marine Science, 2(1):29-36.

Yunus, B., Suwarni, dan A. Irma Santy. 2018. Hubungan Lebar Karapas - Bobot, Faktor Kondisi, dan Kelimpahan Kepiting Bakau Scylla serrata Forsskal, 1775; di Kawasan Pengembangan Silvofishery Jalur Tanggul, Kabupaten Maros. Prosiding Simposium Nasional Kelautan dan Perikanan. 